\title{
Introspecting the Role of Gram Panchayat in Structuring Rural Economy: An Experience from Bhograi Block in Odisha during COVID-19
}

\author{
Dr. Dhirendra Kumar Jena
}

Lecturer, Deptt. of Political Science, RIHS, Bhograi, Balasore, Odisha-756036

\begin{abstract}
PRIs were established with a hope to strengthen the rural India. But during Covid-19, it was experienced that they were not even able to support for livelihood to the rural people. Even in the midst of pandemic, though there was life threat situation, people migrated to cities in search of their livelihood. In this backdrop, this paper highlights the available livelihood supportive infrastructure, livelihood generating base and livelihood supporting mechanisms and schemes and unutilized natural resources in the Gram Panchayats. Particularly, this paper focuses on the strength of Gram Panchayat's self fund, schemes and activities excluding central and state government funding and schemes. The work is produced by the data from both primary and secondary sources. And to make it more scientific, both quantitative and qualitative methods are applied. For this work, Bhograi block of the district of Balasore in Odisha has been taken as area of study. From the study, it is experienced that there is available resources lying unutilised but due to lack of interest, attitude, commitment of the local representatives and officials of Gram Panchayat resources can't be utilized to harness benefits for people creating jobs and engagements. Finally, some remedial measures like behavioural and attitudinal autonomy of the officials, political neutrality, constitution of Panchayat Development Council (PDC) etc. are suggested to over the problem.
\end{abstract}

Keywords: Gram Panchayat, Rural Economy, Bhograi Block, Odisha, COVID-19

\section{INTRODUCTION}

Despite India maintaining the growth rate of around $7 \%$, being one of the fastest growing economies of the world, even today poverty remains to be the most important problem in India. According to the census (2011) there are $69 \%$ of the people live in villages. As the recent census indicates that the population (31\%) living in urban centres has increased tremendously. According to the official estimation of the Indian government (2012) the population of poor was $22 \%$ in the country and more importantly a large population of poor people live in rural areas. Hence, poverty remains a chronic condition for almost more than $35 \%$ of India's rural population. Particularly poverty is very deep among the members of scheduled castes, tribes and women in the country's rural regions. In India more rural poverty prevails majority among Rajasthan, Madhya Pradesh, Uttar Pradesh, Bihar, Orissa, Chhattisgarh and Karnataka states (Pandit and Kulkarni, 2012) $)^{1}$.

The Panchayats are expected to play an important role in rural development in India, particularly during pandemic. Rural economy is the study of rural income and village economies including farm and nonfarm industry for economic growth, development and change size and spatial distribution of production and household units and inters trade. It provides decent jobs, facilitate agricultural growth, which can in turn raise rural incomes, promote higher consumption and lead to significant 
economy-wide multiplier effects. Given the rise in global demand for food, the agricultural sector offers untapped employment opportunity.

In the Indian context, rural development assumes greater significance. Plan documents of both the central and state governments and various committees have emphasized the importance of these bodies in the polity. Five-year plans, specially the second five-year plan, laid special emphasis on the role of Panchayats in rural developments. Second five year plan envisaged a panchayat as responsible for village development keeping transformation of social and economic life of rural areas as its goal of development. It says that, the rural progress depends entirely on the existence of an active organization in the village which can bring all the people, including the weaker sections, in to common programmes to be carried out with the assistance of administration. To achieve this objective the second Five year Plan entailed the Panchayats to perform civic, developmental, land management, land reform and judicial functions. Subsequent plans and policy pronouncements of national leader to emphasize the role of Panchayats in village development.

The role of Panchayati Raj institutions as instruments of rural reconstruction and development needs to be emphasized. They have been reorganized with wider powers and financial resources not merely as institutions of political participation but institutions of social and economic development (Rabinder, 2016) ${ }^{2}$. Panchayati Raj has come to be associated with two broad images. First, it is a government by itself and second it is an agency of the state government. In the integrated exercise of planning for social and economic development, co-ordinate roles, the present set up is a three-tier representative structure of the government where the administrators, elected leaders and local population participate in the developmental effort (Thanikasalam and Saraswathy, 2014) ${ }^{3}$. In fact, the elected representatives play the key role in the decision making process. The leaders are regarded as facilitators of the process of development. Since the emphasis of rural development policies is bringing about people's participation in the development programmes, it is possible to achieve this through the leaders.

\section{Research Problem}

Odisha is rich with natural resources. Out of 314 blocks in Odisha, Bhograi block is significant for its literacy rate, agricultural resource rate and favorable climatic condition. In Balasore district, it has highest literacy rate and also strong agricultural background. So naturally, the Bhograi block is expected to have good livelihood and employment infrastructure but during pandemic it was experienced that many people were in outside state as migrant workers. They had to come back to their native place Bhograi being assured by state govt of getting livelihood income and job but that became a day dream and they had to again migrate outside the state in the midst of pandemic. It seemed to happen due to poor rural economical infrastructure of panchayats under Bhograi block, which is definitely a problem of rural economy and challenged the intention of $73^{\text {rd }}$ amendment act 1992 for Pachayati raj system. This problem sensitized to the present student researchers and they under took it as research problem.

\section{Hypotheses}

The hypothesis is doubtful question about research problem to be proved or disproved. In this respect the present student researchers devised following hypothesis.

1. Whether lack of interest among political representatives and officials for implementation of policies and constitutional provision leads to weak economic structure of Gram panchayats under Bhograi block.

2. Whether ignorance of people leads to un-utilization of resources in panchayats under Bhograi block. 


\section{Objectives}

The objectives are the ways to achieve the main goal. In this respect to analyse the problem and get the solution to the problem the student researchers have undertaken the following Objectives.

1. To study the conceptual background of rural political economy.

2. To examine the behavior pattern and mental attitudes of the stakeholders of gram panchayat of Bhograi for bringing developed rural economy.

3. To study the governmental policy measures of gram panchayat.

4. To evaluate rural development of Bhograi block.

5. To identify the problem of panchayat under Bhograi block in implementing rural development programmes during Covid19.

6. To give suggestion for better implementation of policies and development.

\section{RESEARCH METHODOLOGY}

This study is based on both theoretical and field work. The theoretical work is based on secondary data from books, articles in journals, newspaper and internet sources. Through field work the primary data have been collected on the basis of interview method, group discussion and Participatory Rural Appraisal (PRA). For interview, a structured and printed scheduled of question has been used on the respondents in the sample area i.e. Bhograi block. The student researchers used simple random sampling design and the sample size is fixed as 100 having considered significant limitations. The collected data are encoded, tabulated and analysed using the computer and the SPSS (Statistical Package for Social Science) software. For analysis simple statistics like Percentage, decimal are considered. It has emphasized on qualitative method. In short the work has become scientific, behavioural and triangular.

\section{Significance of study}

This work highlights the problems of weak rural political economy in gram panchayat level. It finds out the weakness of officials, people and policies. There by it suggests some strategies, action and policies to make gram panchayat self- sufficient. So that, it gives idea to generate livelihood scopes and job facilities under sample panchayat in particular and all panchayats of Odisha and India in general. Definitely this work has much significance.

\section{REVIEW OF LITERATURE}

The aim of the literature review is to discover what available knowledge exists related to the present research topic. It helps to find research gaps in published research works on the concerned topic that may generate new original ideas in the present research. The present researcher has undertaken an ideal amount of books, articles etc. for literature review and tried to find out the research gap.

H.R. Chaturvedi and S.K. Mitra conducted a study $(1982)^{4}$ on the administrational aspects in the rural development. The major objective of the study was to examine the nature and extent of citizen participation in rural development. The authors had selected two districts from 2 distinct states. According to them in order to achieve rural development it is very necessary for people participation in these activities, particularly through panchayat raj institutions. Panchandikar $(1978)^{5}$ had attempted to examine the modern aspects in the block level institutions. However, the major focus was on the role of traditional institutions like co-operatives organizations, rural banks, agricultural credit and Panchayat Raj institutions in the process of rural modernisation. As the study indicates that in the above mentioned three blocks there have been numerous programmes implemented by panchayat raj institutions in making villages modern. Amal Ray in his study $(1976)^{6}$ analysed the administration process in the panchayat raj institution, particularly in the taluk level administration on rural development. 
Aziz $(1993)^{7}$ conducted various studies on the process of decentralisation in planning of Karnataka state, which outlines the politico-administrative structure created for undertaking decentralized planning. These studies critically evaluated the implementation of such decentralised planning. The findings of these studies indicate that at the implementation level these panchayat raj institutions achieved excellence but the poor performance was visible at the planning level.

The economic concept of poverty, in terms of external circumstances, conditions a person's behaviour he displays in economic transactions, buying consumption items, selling productive services, securing professional advices, etc. (Watts, $1964)^{8}$.There exists an inverse relationship between economic growth and poverty and the structural reforms can increase the rate of economic growth and consequently reduce poverty (Garza-Rodriguez, 2018) ${ }^{9}$.

\section{Conceptual Framework}

In Indian Constitution under its Directive Principal of State Policy in Article 38 it is clearly mentioned that state shall promote the welfare of the people in terms of justice, social, economical and political perspective. It has also been mentioned that state shall also minimise the inequalities in income and endeavour to eliminate inequalities in status, facilities and opportunities. Article 40 emphasises for formation of village panchayat with such power and authority as may be necessary to enable them to function as units of selfgovernment (Mukherjee \& Mukherjee $2008)^{10}$. Panchayats have been the backbone of the Indian villages since the beginning of the recorded history. Panchayat Raj is a system of governance in which Gram Panchayats are the basic units of administration. Panchayat Raj Institutions (PRIs) have been involved in the programme implementation and they constitute the core of decentralized development of planning and its implementation. Panchayat Raj Institutions aim at translating the Gandhian dream of village self-governance (Gram Swaraj) and to become an effective tool of rural development and reconstruction. Since 1959, almost all rural development departments have been executing their programmes through PRIs. With the implementation of State Acts under the spirit of the 73rd Constitutional Amendment a clear cut role of Panchayat Raj Institutions in rural development has been envisaged. Government of India and the different State Governments are now increasingly seeking the assistance of the Panchayat Raj Institutions in the implementation of various schemes as well as poverty alleviation programmes.

\section{Evolution and Functioning of Panchayat Raj Institutions}

Panchayats are India's ancient autonomous democratic institutions. Description of panchayats is found in the ancient Indian text 'Rigveda' in the form of 'Sabhas' and 'Samities'. Panchayat literally menas assembly (yat) of five (panch) wise and respected elders chosen and accepted by the village community. The philosophy of Panchayat Raj is deeply steeped in tradition and culture of rural India(Vani and Ravindranath, 2017) ${ }^{11}$. It is by no means a new concept. Panchayat Raj provided a system of self-governance at the village level. Panchayat Raj Institutions is the grass root unit of self-government. It has been declared as the vehicle of socio-economic transformation in rural India. Effective and meaningful functioning of these bodies would depend on active involvement contribution and participation of its citizens, both male and female.

\section{Objectives of Panchayat}

The objectives of the Panchayat are 1. Assistance to the economically weaker sections of the community. 2. Cohesion and cooperative self help in the community. 3 . Development of cooperative institutions. 4. Development of local resources including the utilization of manpower. 5. Production in agriculture as the highest priority in 
planning. 6. Progressive dispersal of authority and initiative both vertically and horizontally with special emphasis on the role of voluntary organizations. 7. Promotion of rural industries. 8. Understanding and harmony between the people's representatives and people servants through comprehensive training/education and a clear demarcation of duties and responsibilities.

\section{Organizational Pattern of Panchayats}

Panchayat Raj Institutions have been organized into three-tier system for enlisting people's participation in rural reconstruction, viz., 1. The Gram Panchayat Gram Panchayat is the primary unit of Panchayat Raj Institutions or local selfgovernment. It is considered as the first formal democratic institution under the directive principle in the Indian constitution. It is a cabinet of the village elders, directly elected by the adult citizens of the village. The Panchayat has tenure of five years and is directly elected. It has income through taxes to perform its functions.

\section{Main Functions of Village Panchayats}

1. Preparation of Annual Plans for the development of the village Panchayat area. 2. Preparation Annual Budget of Village Panchayat. 3. Mobilization of relief in natural calamities. 4. Removal of encroachments on public properties. 5. Organizing voluntary labours and contribution for community works. 6 . Maintenance of essential statistics of villages. 7. Such other development works as may be entrusted. 8. Service or developmental function, such as promotion of education, health, agriculture, etc. 9. Representative function, where the main role is to voice and represent the opinion; 10. Regulatory and administrative functions, which consists of regulating the conduct of individuals and institutions and also collection of taxes.

\section{Sources of Income of Village Panchayats}

1. Share in land revenue. 2. Local tax. 3. Revenue earned from the settlement of shops, fisheries, etc 4. House taxes \& other taxes as specified in Panchayat Raj Act. 5. Fees for providing amenities, cess, tolls. 6. Contribution and grants. 7. Fine and penalties.

\section{Challenges to Rural Economy}

The concept of rural economy we are discussing about is not new one. The basis of rural economy targets to rural village which constitute $80 \%$ of India. Emphasising development of rural areas Pandit Nehru with his characteristic longrange vision and idealism went to the extent of saying, "democracy is not merely parliament at the top or in the states, but something that excites every person and indeed any place in the country if need arises" (Thanikasalam and Saraswathy, 2014) $)^{12}$, Gandhiji drew the picture of free India's political structure in these words, "Indian independence must begin at the bottom. Every village should be a republic or a Panchayat having full powers. The greater the power of Panchayats, the better it is for the people". "Swaraj" signified to him the vesting of the ultimate authority in the peasant and the labourer. True democracy cannot be worked from bellow by the people of every village (Ibidi) ${ }^{13}$.

\section{Challenges}

The effective involvement of the Panchayat Raj Institutions in the process of rural economy is constrained by some difficulties facing these institutions as follows:

\section{Autonomy}

There are many constitutional provisions for autonomy of gram Panchayat but the reality is different in case of practice. This autonomy simply is in pen and rs paper. It has been given wide powers and functions but practically these powers and functions are not practice many times. The political representatives in the panchayat level neither autonomy in psychologically no physically. Generally during election, Sarapancha candidate is not 
proposed by any person from political parties. Further he/she is not given with any political party symbol, intending to keep the wining candidates out of party politics. There by in future he/she may not come under influence of any political party. This keeps his/her autonomy protected. The head of the panchayat can exercise his powers and functions independently. So that, he/she can function with his/her own idea collected from experience from the grass-root level. By this, he can be guided by the sense of his/her conscience and spirit of the constitution. But it is pathetic that practice has been a day dream. The head of the panchatyat and villages do not do a single work from their own ideas. Even, they are forced by their political boss the as per their command but not command their reason. The case is with regard lower level of officials, those were working in gram panchayat level, they don't have any freedom to act as per their own wish and will complementary to benefit of the people. Definitely they have to obey the order of the higher officials those who are sitting in the AC room. In short both political representatives, public officials and Gram panchayat itself are in façade autonomy.

\section{Interest, attitude and commitment}

Interest, attitudes and commitment are catalysts for doing any work most of the time people officials and political representatives are not trust worthy to these three things people don't have any interest to bell the cat. They are like, lifeless they bear everything against them, they didn't give input properly to established new projects to launch new schemes by Gram panchayats. Rather they prefer to go outside as migrant labourers. This type of passivism and pessimism suit to both political representative and public officers. They exploit these situations either sitting ideal or filling their pocket by exploiting otherwise. They don't think about self-reliance and village panchayat they are not committed to effect the provisions and policies so far development of Gram panchayat of concerns.

\section{Dependency}

The intention of the $73^{\text {rd }}$ amendment act was to transform village or Gram panchayat self-reliant, independence and autonomous republic. This could be possible, if village or village panchayats will be kept along and independent. There are many sources of income for panchayats are laid down in the laws and policies after $73^{\text {rd }}$ amendment act. For example, village panchayats can collect taxes from locality so far street electrification, organizing market, house taxing, public toilet, fine and penalties etc. But it is tragedy that panchayat authority are only hankering after either state fund or central fund. There by, they are so busy in dealing with these funds that they are shortage of time to deal with panchayat own funds. That's why, panchayat own funds is very less. The gram panchayat has been so poor and dependent that it dances on the tune of either central government and state government. There is no question of running panchayat own schemes and projects.

\section{Knowledge, innovation and training}

Very root of knowledge is practice. The person, those who are dealing the problems can have better knowledge to deal with the problems. So person those, who are experiencing in the grass-root must have knowledge and innovation but it is experienced that some egoistic officers and political representatives are sought of new knowledge and innovation to stand a new projects and schemes on behalf of gram panchayat without depending state and central government. That's why the available natural resources are not exploited sustainably. Further these persons are not properly trained to harness new generating schemes from existing natural resources.

\section{Follow of action}

The very important strategy to effect anything is follow up action. Maximum policies and plans in India especially rural 
areas are failed due to lack of follow up action. This small schemes and large of rural areas are not properly inspected on for which loss and loss has only been the result, when it happens frequently the authority of the panchayats will be noted further interest. So it is big drawback for strengthening rural economy.

\section{Socio-Economic Profile of the Study Area}

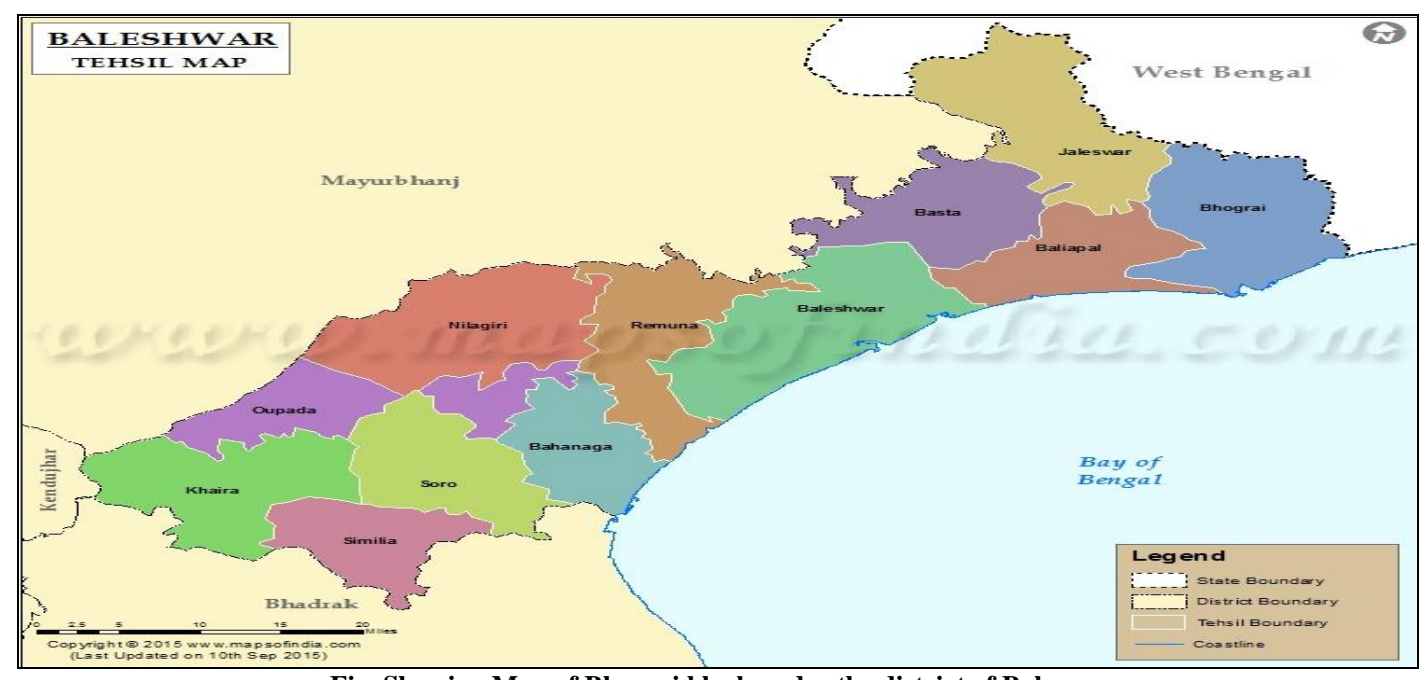

Fig. Showing Map of Bhograi block under the district of Balasore

The total population of Bhograi block is $2,83,880$. Out of which $1,46,843$ are males and 1,37,037 are females. The total SC population is 52,482 , out of which 26,728 are male and 25,754 are female and ST population is 7,193 out of which male are 3626 and female are 3,567. The average sex ratio of Bhograi block is 936 while child sex ratio is 923. The rate of literacy in Bhograi block is $84.67 \%$. Male literacy is $91.95 \%$ and the female literacy rate is $76.91 \%$ in Bhograi block (Census India, $2011)^{14}$.

\section{Findings and Analysis}

In this work the researcher has many findings to his credit. He has tested the
There are 12 blocks in the district of Balasore. Out of them, Bhograi block is the largest. It is consisted of 50 gram panchayats. It is situated in the extreme North-Eastern part of the district. It is partly encircled by Bay of Bengal. The state of West Bangal is very adjacent to the Bhograi block. The river Suvarnarekha is running in the block. According to 2011 census

cerned hypotheses on the basis of the data collected in the field study. He has tried his best to study the perceptions of the respondents i.e. people of Bhograi block under the district of Balasore to analyze the problems and probable solutions of the problem. He collected data from 100 respondents cautiously and systematically.

The researcher before analysing the data; to test the hypothesis wanted to check the available resources having capability for income generation in the grampanchayat. So, he put a question, i.e. which income generating source is available in his/her grampanchayat.

Table no 1. Responses showing income generating sources available in the Grampanchayat

\begin{tabular}{|c|l|c|c|c|c|}
\hline \multicolumn{2}{|c|}{} & Frequency & Percent & Valid Percent & Cumulative Percent \\
\hline \multirow{3}{*}{ Valid } & Fishery and Market & 70 & 70.0 & 70.0 & 70.0 \\
\cline { 2 - 6 } & I Can't Say & 30 & 30.0 & 30.0 & 100.0 \\
\cline { 2 - 6 } & Total & $\mathbf{1 0 0}$ & $\mathbf{1 0 0 . 0}$ & $\mathbf{1 0 0 . 0}$ & \\
\hline
\end{tabular}

In reactions (shown in table 6.1), 70 (70\%) respondents replied of having fishery and local market (Hata) as the income generating sources for panchayat. Whereas $30(30 \%)$ respondents responded "I can't say", which shows this percentage of people 
are ignorant about society and political status of gram panchayat.

Further, to test the availability of jobs in the grampanchayat, which was bare need during covid-19 pandemic; the researcher asked the question whether grampanchayat gives job to the local people coming under its own schemes and projects. The intention behind the question was simply to know whether panchayat runs any existing schemes and projects. In reaction (table 2), $50(50 \%)$ and $28(28 \%)$ opted 'disagreed' and 'strongly disagreed' respectively.

Table No 2: Responses showing whether Grampanchayat gives job to the people by its own schemes and projects

\begin{tabular}{|c|c|c|c|c|c|}
\hline & Frequency & Percent & Valid Percent & Cumulative Percent \\
\hline \multirow[t]{6}{*}{ Valid } & Strongly Agreed & 6 & 6.0 & 6.0 & 6.0 \\
\hline & Agreed & 8 & 8.0 & 8.0 & 14.0 \\
\hline & Undecided & 2 & 2.0 & 2.0 & 16.0 \\
\hline & Disagreed & 56 & 56.0 & 56.0 & 72.0 \\
\hline & Strongly Disagreed & 28 & 28.0 & 28.0 & 100.0 \\
\hline & Total & 100 & 100.0 & 100.0 & \\
\hline
\end{tabular}

Whereas $6(6 \%)$ and $8(8 \%)$ replied 'strongly agreed' and 'agreed' on the questions. Further, $2(2 \%)$ were undecided to respond the question. From the above statistics, it can be analysed that, grampanchayat though have income generating sources, it has failed to launch schemes and projects for income generation to be meant for development of rural economy and absorption local youth in the grampanchayat preventing from going outside as migrant labourer.

Again availability of natural resource was checked by the researcher; the statistics which is shown in table no 3. From the study, it is experienced that $44(44 \%)$ respondents replied that, there is government land in the panchayat. 38 out of 100 told that there is also pond in the panchayat. $2(2 \%)$ and $16(16 \%)$ respondent opted 'forest' and 'others if any'.

Table No 3: Responses showing type of natural resources available in the panchayat for self income generating

\begin{tabular}{|c|c|c|c|c|c|}
\hline \multicolumn{2}{|c|}{ 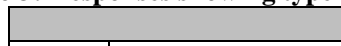 } & Frequency & Percent & Valid Percent & Cumulative Percent \\
\hline \multirow{5}{*}{ Valid } & Government land & 44 & 44.0 & 44.0 & 44.0 \\
\hline & Pond & 38 & 38.0 & 38.0 & 82.0 \\
\hline & Forest & 2 & 2.0 & 2.0 & 84.0 \\
\hline & Others if any & 16 & 16.0 & 16.0 & 100.0 \\
\hline & Total & 100 & 100.0 & 100.0 & \\
\hline
\end{tabular}

From this statistics, it is clear that panchayat has sufficient natural resources for harnessing livelihood income for local people by engaging in various agro-based schemes and projects. But the panchayat has utterly failed to do it. For which it failed to keep the people in their panchayat during dreadful Covid19 pandemic.

Now, the researcher tried to test the hypothesis no-1, i.e. whether lack of interest among political leaders and officials for implementations for policies and constitutional provisions is responsible to weaken the economy of gram panchayat. The details statistics has been given in table no-4. Here, the researcher asked question whether local political leader raises the issue of income generating schemes in Palli or Gram Sabha.

Table No 4: Responses showing whether Local political leaders raises the issue of income generating scheme in Palli Sabha/Gram sabha.

\begin{tabular}{|c|l|c|c|c|c|}
\hline \multicolumn{2}{|c|}{} & Frequency & Percent & Valid Percent & Cumulative Percent \\
\hline Valid & Strongly Agreed & 4 & 4.0 & 4.0 & 4.0 \\
\cline { 2 - 6 } & Agreed & 6 & 6.0 & 6.0 & 10.0 \\
\cline { 2 - 6 } & Disagreed & 52 & 52.0 & 52.0 & 62.0 \\
\cline { 2 - 6 } & Strongly Disagreed & 38 & 38.0 & 38.0 & 100.0 \\
\cline { 2 - 6 } & Total & $\mathbf{1 0 0}$ & $\mathbf{1 0 0 . 0}$ & $\mathbf{1 0 0 . 0}$ & \\
\hline
\end{tabular}

In response, $52(52 \%)$ respondents reacted 'disagreed' and $32(32 \%)$ reacted 'strongly disagreed' of political leaders raising the issue of such schemes in Palli or 
Dr. Dhirendra Kumar Jena. Introspecting the role of gram panchayat in structuring rural economy: an experience from Bhograi block in Odisha during COVID-19

Gram sabha. On the others hand, only 4 $(4 \%)$ and $6(6 \%)$ reacted with 'strongly agreed' and 'agreed' respectively.

Further the researcher enquired whether officials organized any awareness programmes for creating income generating structure in the panchayat. In response (table 5), $90(90 \%)$ replied with 'No', where as only $10(10 \%)$ answered with 'Yes'.

Table no 5: Responses showing whether the officials organize any awareness programme for creating income generating structure in your panchayat?

\begin{tabular}{|c|l|c|c|c|c|}
\hline \multicolumn{2}{|c|}{} & Frequency & Percent & Valid Percent & Cumulative Percent \\
\hline Valid & Yes & 10 & 10.0 & 10.0 & 10.0 \\
\cline { 2 - 6 } & No & 90 & 90.0 & 90.0 & 100.0 \\
\cline { 2 - 6 } & Total & $\mathbf{1 0 0}$ & $\mathbf{1 0 0 . 0}$ & $\mathbf{1 0 0 . 0}$ & \\
\hline
\end{tabular}

From the above two cases, it can be analyzed that due to lack of interest among both political leaders and government officials; no income generating schemes and projects are run in the Gram panchayat to strengthen rural economy of the Gram panchayat, which may be the main factor for huge migration from the rural area of Bhiograi Block. In this connection the hypothesis no 1 is accepted.
Again, the researcher tried to test the hypothesis no-2, i. e. whether ignorance of people is responsible for weakening the economic structure of grampanchayat. To test this, the researcher asked some question to know the level of political awareness, sincerity, commitment and sprit of the people.

Table No 6: Responses showing the political status of Grampanchayat ?

\begin{tabular}{|c|l|c|c|c|c|}
\hline \multicolumn{2}{|c|}{} & Frequency & Percent & Valid Percent & Cumulative Percent \\
\hline Valid & Autonomous & 58 & 58.0 & 58.0 & 58.0 \\
\cline { 2 - 6 } & Affiliated & 2 & 2.0 & 2.0 & 60.0 \\
\cline { 2 - 6 } & Dependent & 28 & 28.0 & 28.0 & 88.0 \\
\cline { 2 - 6 } & Others if any & 12 & 12.0 & 12.0 & 100.0 \\
\cline { 2 - 6 } & Total & $\mathbf{1 0 0}$ & $\mathbf{1 0 0 . 0}$ & $\mathbf{1 0 0 . 0}$ & \\
\hline
\end{tabular}

Firstly, they asked the question i.e. 'what is the political status of gram ponchayat? In response (as shown in table 6), $58(58 \%)$ respondents said panchayat has 'autonomous status', 2 (2\%) replied as 'affiliated status' and 28 (28\%) respondent said it has dependent status. Anyway, this is a good sign of understanding by the people, which is exceptional.

Further, researcher wanted to have the knowledge of the people about migrant workers from their panchayat.

Table No 7. Responses showing whether the people of your panchayat working as laborers outside the state

\begin{tabular}{|c|l|c|c|c|c|}
\hline \multicolumn{2}{|c|}{ Valid } & Frequency & Percent & Valid Percent & Cumulative Percent \\
\cline { 2 - 6 } & No & 84 & 84.0 & 84.0 & 84.0 \\
\cline { 2 - 6 } & I cant say & 8 & 8.0 & 8.0 & 92.0 \\
\cline { 2 - 6 } & Total & $\mathbf{1 0 0}$ & 8.0 & 8.0 & 100.0 \\
\hline
\end{tabular}

To the questions whether people of their panchayat working as 'migrant labour' outside the state. $84(84 \%)$ replied 'Yes' and only $8(8 \%)$ replied 'No'. Further to know what may be the cause of going outside for job, $100 \%$ told it is due to economy factor.

Further, the researcher asked the respondents, whether Gram panchayata is empowered to create its own economy infrastructure. The statistics of this inquiry is given in table no- 8 . In reaction, $32(32 \%)$ and $26(26 \%)$ reacted with 'strongly disagreed' and 'agreed' respectively. However $18(18 \%)$ and $16(16 \%)$ reacted with 'disagree' and 'strongly disagreed'. But $8(8 \%)$ reacted as on 'undecided'. From above statistics, it is proved that, the people are conscious about political status. So, the hypothesis no 2 is rejected. If matter is so, one thing comes into the mind of the researcher, why don't people as well as panchayat start and run income generating schemes and projects for the benefits of the 
Dr. Dhirendra Kumar Jena. Introspecting the role of gram panchayat in structuring rural economy: an experience from Bhograi block in Odisha during COVID-19

people. If it happens there will be no migrants workers.

Table no 8: Responses showing whether Grampanchayat is empowered as autonomous body to create its own economic infrastructure to provide livelihood income to the people.

\begin{tabular}{|c|l|c|c|c|c|}
\hline \multicolumn{2}{|c|}{} & Frequency & Percent & Valid Percent & Cumulative Percent \\
\hline Valid & Strongly Agreed & 32 & 32.0 & 32.0 & 32.0 \\
\cline { 2 - 6 } & Agreed & 26 & 26.0 & 26.0 & 58.0 \\
\cline { 2 - 6 } & Undecided & 8 & 8.0 & 8.0 & 66.0 \\
\cline { 2 - 6 } & Disagreed & 18 & 18.0 & 18.0 & 84.0 \\
\cline { 2 - 6 } & Strongly disagreed & 16 & 16.0 & 16.0 & 100.0 \\
\cline { 2 - 6 } & Total & $\mathbf{1 0 0}$ & $\mathbf{1 0 0 . 0}$ & $\mathbf{1 0 0 . 0}$ & \\
\hline
\end{tabular}

To know the cause of not initiating the income generating projects and schemes. The researcher asks, what are the obstruction for good economic development in the panchayat. In reaction $58(58 \%)$ told that economic development has not been possible, due to less interest of local political representatives. $22(22 \%)$ respondents attributed that there is obstruction for good economic development is due to lack of real freedom and power to panchayat by government.

Table No 9: Responses showing what are the obstruction for good economic development of your panchayat
\begin{tabular}{|l|c|c|c|c|}
\hline \multicolumn{1}{|c|}{ Frequency } & Percent & Valid Percent & Cumulative\% \\
\hline Government land & 2 & 2.0 & 2.0 & 2.0 \\
\hline Less interest of local representative & 58 & 58.0 & 58.0 & 60.0 \\
\hline Lack of coordination between people, official and Political representative & 2 & 2.0 & 2.0 & 62.0 \\
\hline Lack of real freedom and power to Panchayat by Government & 22 & 22.0 & 22.0 & 84.0 \\
\hline Dominated by higher authority & 6 & 6.0 & 6.0 & 90.0 \\
\hline Others if any & 10 & 10.0 & 10.0 & 100.0 \\
\hline \multicolumn{1}{|c|}{ Total } & $\mathbf{1 0 0}$ & $\mathbf{1 0 0 . 0}$ & $\mathbf{1 0 0 . 0}$ & \\
\hline
\end{tabular}

Each $2(2 \%)$ told government land is under the possession of private people and lack of coordination among people, officials and political representative respectively are causes of obstruction of good economic development of the panchayat. Further 6 (6\%) opined that due to dominations of higher authority good economic development of the panchayat has never been possible. However, 10 (10\%) opted minor reasons which are categorised as 'others if any'.
Again, researcher asked the questions, what may be the solution for independent and developed economy of panchayats. In reactions (table 10), 30 (30\%) respondents responded that there should be agro-industry in the rural area. 24 out of 100 replied that, there should be cottage industry in the rural area. Further, $10(10 \%)$ and $20(20 \%)$ emphasized on the development of agriculture and financial support respectively for the economic development of panchayat.

Table No 10: Responses showing what may be solution for the development of self economy of panchayat

\begin{tabular}{|c|l|c|c|c|c|}
\hline \multicolumn{2}{|c|}{} & Frequency & Percent & Valid Percent & Cumulative Percent \\
\hline Valid & Making agro Industry & 30 & 30.0 & 30.0 & 30.0 \\
\cline { 2 - 6 } & Cottage Industry & 24 & 24.0 & 24.0 & 54.0 \\
\cline { 2 - 6 } & Development of agriculture & 10 & 10.0 & 10.0 & 64.0 \\
\cline { 2 - 6 } & Financial Support & 12 & 12.0 & 12.0 & 76.0 \\
\cline { 2 - 6 } & I can't say & 24 & 24.0 & 24.0 & 100.0 \\
\cline { 2 - 6 } & Total & $\mathbf{1 0 0}$ & $\mathbf{1 0 0 . 0}$ & $\mathbf{1 0 0 . 0}$ & \\
\hline
\end{tabular}

However 24(24\%) showed their inability to suggest in any manner. From the above statistics, it is revealed that, panchayat has both resources and people to work out. The only need of hour is to change the attitude and intentions of people, political representative, government officials and government itself. There should be holistic, integrated and spirited approach to effect the natural and human resources in the gram panchyata. So, that we can fight out what ever may be impact of pandemic. 


\section{SUGGESTION AND CONCLUSION}

The core of this work is to highlight what is the own ability of the gram panchayat to protect the people. The intention of panchayat raj system is to make panchayat self-reliant and self-dependent. Gram panchayat might be doing many things but focus of this work is how without assistance of central and state government fundings; the panchayat can harness various schemes and projects to give livelihood benefits to the people. The Covid19 pandemic is the root of this work. During Covid19 pandemic it is experienced that all the sectors of livelihood had failed except agriculture. Further, it was also experienced that finally Gram panchayats failed to check migrant workers' flow to others state. In other words, Gram panchayat could not provide the livelihood guarantees to the migrant workers. So that, people went outside in the midst of dreadful and life threatening Covid19 pandemic. This critical juncture must have affected all the experts of rural development, researchers, academicians, statesmen etc. This is high time to think how panchayat will be selfreliant and create livelihood guarantees for the people. So that people will not go outside for their livelihood. Following suggestion may be prescribed to make the Gram panchayat self reliant in economy.

1. First of all, people representatives should understand that, they are representing the people. They should have sense of accountability to the people. They should prioritize sense of reason rather than to follow bossism. They should be committed to make their gram panchayat self-reliant.

2. Every Gram panchayat should have panchayat development Council (PDC) headed by Sarapancha and its members must be good planners, researchers and bureaucrats with neutral background.

3. The officials of Gram panchayat should maintain neutrality and must be committed to build up the panchayat self-reliant by exploiting natural resources sustainably.
4. Both political representatives and officials should be trained with limited members through different seminars and workshop etc.

5. There should be participatory and interactive strategies among people, government officials and local representatives.

6. There should be use of existing natural resources with updating manners and creation of new schemes and projects. Further, proper revenue taxes should be levied and collected.

7. There should be stringent follow up action observed for smooth running and success of plans, programs, schemes and projects.

\section{Conclusion}

In conclusions, the Covid19 pandemic has taught us how to be selfreliant and self-dependent. Further, it has proved that agricultural sector is only sustainable sector which can protect our lives at any situation. So, through village panchayat, we have to create sustainable economy model especially with strong rural economy.

\section{Acknowledgement: None}

\section{Conflict of Interest: None}

\section{Source of Funding: None}

\section{REFERENCES}

1. Pandit A.S. and Kulkarni B.V. (2012). "The Role of Jat Panchayat in Rural Development". Online International Interdisciplinary Research Journal.

2. Ravinder L (2016) Role of village panchayat in Rural Development: A Study of Paathiapaka village Warangal District, International Research Journal of Human Resources and Social Sciences, Vol.3, Issue 6, June, $\mathrm{p} 1$.

3. Thanikasalam, S. and Saraswathy, S. (2014), Role of Gram Panchayat in Rural Development: A Study of Vagurani Village of Usilampatti Block of Madurai, District (Tamil Nadu), International Journal of Humanities and Social Science Invention, Volume 3 , Issue 1 January \| PP.49-56. 
Dr. Dhirendra Kumar Jena. Introspecting the role of gram panchayat in structuring rural economy: an experience from Bhograi block in Odisha during COVID-19

4. Chaturvedi, H.R. and Mitra, S.K. (1982) Citizen Participation in Rural Development, New Delhi, Oxford and IBH Co.

5. Panchandikar. (1978). "Rural Modernisation in India". Bombay.

6. Ray, Amal. (1976). "Organizational aspect of Rural Development". Calcutta: World Press.

7. Aziz, Abdul (1993). "Decentralisation; Mandal Panchayat System in Karnataka". Hyderabad.

8. Watts, H. W. (1964). An Economic Definition of Poverty. Wisconsin: The University of Wisconsin.

9. Garza-Rodriguez, J. (2018). Poverty and Economic Growth in Mexico. Social Sciences, 183.

10. Mukherjee, S., \& Mukherjee, I. (2008). The Constitution of India. Kolkata: The World Press Private Limited

11. Vani H and Ravindranath N. Kadam (2017), Panchayat Raj Institutions and Rural Development In India-Structural And Functional Dimensions, International
Journal of Science Technology and management, Vol. 6, Issue 6, June

12. Thanikasalam, S. \& Saraswathy, S. (2014), Role of Gram Panchayat in Rural Development: A Study of Vagurani Village of Usilampatti Block of Madurai, District (Tamil Nadu), International Journal of Humanities and Social Science Invention, Volume 3, Issue 1 January \| PP.49-56 .

13. Ibidi

14. Census India (2011) Bhograi Population, caste Religion Data, accessed from https://www.censusindia.co.in/subdistrict/bh ograi-block-baleshwar-odisha-2891 on dtd 19/7/2021

How to cite this article: Jena DK. Introspecting the role of gram panchayat in structuring rural economy: an experience from Bhograi block in Odisha during COVID-19. Galore International Journal of Applied Sciences \& Humanities. 2021; 5(3): 35-46. DOI: https://doi.org/ 10.52403/gijash.20210705 